\title{
Extending the Vase Life of Cut Gerbera (Gerbera jamesonii Bolus ex. Hook) cv. Savannah by Using Locally Available Floral Preservatives under Ambient Storage
}

\author{
K. C. Bhanu Murthy ${ }^{1 *}$, P. Prashanth ${ }^{2}$ and R. Chandrasekhar ${ }^{3}$ \\ ${ }^{1}$ Dept. of Floriculture and Landscape Architecture, College of Horticulture, Dr. Y. S. R. Horticultural University, \\ Rajendranagar, Hyderabad, Telangana (500 030), India \\ ${ }^{2 \& 3}$ Dept. of Floriculture and Landscape Architecture, College of Horticulture, Dr. Y. S. R. Horticultural University, \\ Mojerla, Hyderabad, Telangana (500 030), India
}

\section{Article History}

Manuscript No. AR1113

Received in $24^{\text {th }}$ November, 2014

Received in revised form $4^{\text {th }}$ April, 2015

Accepted in final form $29^{\text {th }}$ May, 2015

\section{Correspondence to}

"E-mail: k.c.bhanumurthy1989@gmail.com

\section{Keywords}

Gerbera, scape bending, neem extract, vase life, microbial count

\begin{abstract}
A laboratory trial was carried out to investigate the effectiveness of different locally available floral preservatives on extension of vase life of cut gerbera cv. Savannah under ambient storage condition. All the cut gerberas were precooled at $5{ }^{\circ} \mathrm{C}$ for 6 hours and followed by pulsing with sucrose at $20 \%+$ sodium hypochlorite at 50 ppm for 12 hours and then kept in locally available preservative floral solutions i.e. sugar, commercial vinegar, lime (Citrus aurantifolia) juice, commercial bleach (calcium hypochlorite- $\mathrm{CaOCl}_{2}$ ) and neem (Azadirachta indica) extract at different concentrations in combination with $4 \%$ sucrose. Using the solution of neem extract at $1 \%$ coupled with $4 \%$ sucrose significantly maintained water relations and reduced scape bending curvature as compared to all other treatments. Total soluble solids in flower stalk and anthocyanin content in ligules of cut gerberas kept in neem extract at $1 \%+4 \%$ sucrose solution were also highest i.e. ( $10.08^{\circ}$ Brix) and (5.83 $\mathrm{mg}$ Congo Red g $^{-1} \mathrm{f} \mathrm{wt}$ ) respectively. The cut gerberas held in solution of neem extract at $1 \%+$ sucrose at $4 \%$ recorded lowest optical density $(0.041)$ which was attributed with lowest microbial count $\left(4.26 \times 10^{5} \mathrm{cfu} \mathrm{ml}^{-1}\right)$ and resulted in highest vase life (11.76 days) compared to control (4.53 days) which recorded highest microbial count $\left(8.99 \times 10^{6} \mathrm{cfu} \mathrm{ml}^{-1}\right)$.
\end{abstract}

\section{Introduction}

Gerbera (Gerbera jamesonii Bolus ex. Hook.) belongs to Asteraceae family, the largest family of flowering plants and is one of ten popular cut flowers in the world, according to global trends in floriculture (Soad et al., 2011). It is in considerable demand in both domestic and export market. The blooms are attractive, suitable for any type of floral arrangements and are available in different shades and hues. Besides floral arrangements, gerbera is widely used in bouquets and also in dry flower crafts.

Keeping quality is an important parameter for evaluation of cut flower quality for both domestic and export markets. Most floral preservatives contain germicides, ethylene synthesis inhibitors, growth regulators, mineral compounds and carbohydrates that are essential to extend the vase life of cut flowers (Mutui, 2002). Sucrose is widely used in floral preservatives, which acts as a food source of respiratory substrate and delays the degradation of proteins, improves the water balance of cut flower. Treatment of flowers with solutions containing sucrose (5-15\%) improves the vase life of carnation and Gladiolus sp. (Mor et al., 1981). The vase life of gerbera cv. Dune flowers were significantly increased by addition of $6 \%$ sucrose in preservative solution (Mousa et al., 2009).

The major postharvest problem in gerbera is short vase life because of its hollow nature of flower stalk (scape) with bigger sized capitulum on top. The physiological loss in weight is very fast due to the hollowness of scape and also overweight of flower head, the scape gets bend after harvest called as scape bending (Prashanth et al., 2007). Moreover, cut gerberas are sensitive to microbial contamination at the stem end and causes water imbalance in xylem vessels that shortens their vase life (Balestra et al., 2005). Proper harvesting, postharvest handling and use of suitable floral preservatives improve keeping quality of cut gerberas by maintaining the turgidity of scapes. Several attempts have been made to prolong the vase life of cut gerberas by using commercial floral preservatives viz. Florissant, Chrysal, Bloom life, Petal life, Rose life etc. However, these 
preservatives are costly and out of reach for most of small scale cut flower growers, hence the use of locally available floral preservatives viz. sugar, commercial vinegar (acetic acid 4-5\%), lime (Citrus aurantifolia) juice has citric acid content of $4-6 \%$, commercial bleach (calcium hypochlorite- $\mathrm{CaOCl}_{2}$ ) which contains active ingredient of $15-20 \%$ chlorine and neem (Azadirachta indica) extract would be handy and cheaper. Commercial vinegar and lime juice lowered the $\mathrm{pH}$ of the vase solution and allow the stems to uptake the solution more easily (Thwala et al., 2013) whereas commercial bleach (Tsegaw et al., 2011) and neem extract (Chandrasekhar and Gopinath, 2000) have antimicrobial properties, which results in extension of vase life of cut flowers. In this context, the objective of this study was to investigate the effect of locally available floral preservatives in combination with sucrose at different concentrations on extension of vase life of cut gerberas.

\section{Materials and Methods}

The present study was carried out in laboratory conditions at the Department of Floriculture, College of Horticulture, Mojerla from December 2013 to May 2014. Cut gerbera flowers of cultivar Savannah were obtained from a commercial polyhouse located $15 \mathrm{~km}$ away from laboratory. The flowers were harvested when the ray florets at $3 / 4^{\text {th }}$ opened stage in the morning hours between 7 and $8 \mathrm{am}$, wrapped in craft paper in groups and translocated vertically under dry condition to the laboratory within an hour. The cut flowers were immediately unpacked, sorted based on quality of capitulum and stalk length to $40 \mathrm{~cm}$ each in order to maintain uniformity within the replications. The flower scapes were precooled at $4 \pm 2{ }^{\circ} \mathrm{C}$ by placing in precooling chamber and then scapes were placed in the pre-conditioning solution i.e. sucrose at $20 \%+$ sodium hypochlorite $(\mathrm{NaOCl})$ at $50 \mathrm{ppm}$ for pulsing at ambient temperature $\left(22 \pm 2{ }^{\circ} \mathrm{C}\right)$. All the treatments were replicated thrice with completely randomized design with 15 flowers per treatment.

After completion of pulsing, flower scapes were placed in glass bottles containing $250 \mathrm{ml}$ of preservative solution's i.e. sugar at $2 \%\left(\mathrm{~T}_{1}\right)$, sugar at $4 \%\left(\mathrm{~T}_{2}\right)$, commercial vinegar at $2 \%$ $\left(\mathrm{T}_{3}\right)$, commercial vinegar at $4 \%\left(\mathrm{~T}_{4}\right)$, lime (Citrus aurantifolia) juice at $2 \%\left(\mathrm{~T}_{5}\right)$, lime (Citrus aurantifolia) juice at $4 \%\left(\mathrm{~T}_{6}\right)$, commercial bleach (calcium hypochlorite- $\mathrm{CaOCl}_{2}$ ) at $50 \mathrm{ppm}$ $\left(\mathrm{T}_{7}\right)$, commercial bleach (calcium hypochlorite- $\mathrm{CaOCl}_{2}$ ) at $100 \mathrm{ppm}\left(\mathrm{T}_{8}\right)$, neem (Azadirachta indica) extract at $2 \%\left(\mathrm{~T}_{9}\right)$, neem (Azadirachta indica) extract at $4 \%\left(\mathrm{~T}_{10}\right)$, control $\left(\mathrm{T}_{11}\right)$ with distilled water and for treatments $\mathrm{T}_{3}$ to $\mathrm{T}_{10}, 4 \%$ sucrose was supplemented and evaluated their vase life for the rest of the experimental period. All treatments were replicated thrice for confirmation of results and also same set of treatments were ran for biochemical analysis simultaneously. The experimental flowers were held in the laboratory at ambient room temperature $\left(22 \pm 2{ }^{\circ} \mathrm{C}\right), 60$ to $70 \%$ relative humidity and $40 \mathrm{~W} / 84 \mathrm{cool}$ white fluorescent tubes for maintaining 12 hours photoperiod.

\subsection{Observations recorded}

Physiological parameters viz., water relations-water uptake $(\mathrm{g} / \mathrm{f})$, transpirational loss of water $(\mathrm{g} / \mathrm{f})$, fresh weight change (\%) were recorded according to Venkatarayappa et al. (1981), physical parameters like scape bending curvature in degrees given by Van Doorn and De Wittie (1994) at an interval of two days, biochemical parameters viz., total soluble solids in flowers stalk ( ${ }^{\circ}$ Brix), anthocyanin content in mg Congo Red/ gram fresh weight of ligules based on the method given by Rutland (1968), optical density of vase solution (at $480 \mathrm{~nm}$ ) at an interval of three days, vase life according to Abadi et al. (2013) and microbial count given by Bleeksma and Van Doorn (2003) were determined. The data recorded were statistically analyzed as per method described by Panse and Sukhatme (1989).

\section{Results and Discussion}

\subsection{Water relations}

All the treatments showed higher water uptake and increment in weight initially and began to decrease thereafter. However, from day 4 , water uptake was no longer effective to increase the fresh weight of the flowers and the weight began to drop. Data presented in (Table 1). indicated that the treatment neem extract at $1 \%$ supplemented with $4 \%$ sucrose recorded significantly highest water uptake $(9.36 \mathrm{~g} / \mathrm{f})$, transpirational loss of water $(9.31 \mathrm{~g} / \mathrm{f})$. The fresh weight change registered was also highest (94.84\%) whereas the control (distilled water) showed a rapid loss of weight of flowers with poor water uptake and continued throughout the experiment. Generally, declining of water uptake by flowers when placed in holding solution is due to vascular blockage particularly at stem base due to growth of microbes. However, better water relations in treatment neem extract at $1 \%+4 \%$ sucrose might be due to its antimicrobial property, which has prevented growth of microbes which in turn inhibited the plugging of water conducting tissues. Moreover, the sucrose treatment also played its role in registering good water relations in cut gerberas, as sucrose acts as a respiratory substrate and as an osmolite.

\subsection{Scape bending curvature}

It is vivid from the Table 1 that cut gerberas held in treatment with neem extract at $1 \%+4 \%$ sucrose recorded lowest scape bending curvature (4.16 degree) followed by sugar at $4 \%$ (6.04 degree) whereas control (distilled water) registered highest (29.47 degree). Neem extract at 1\% supplemented with 
$4 \%$ sucrose was most effective in controlling scape bending curvature which might be due to positive water relations that resulted in higher turgidity of scapes, delayed senescence and also might have prevented vascular occlusion by reducing the microbial growth in vase solution due to antimicrobial properties.

\subsection{Total soluble solids of flower stalk (TSS)}

Data in (Figure 1). revealed that total soluble solids in stalk of gerbera flowers were increased up to $3^{\text {rd }}$ day in all treatments except control (distilled water) and then from day 3 onwards decreased throughout the experiment. The treatment neem extract at $1 \%+$ sucrose at $4 \%$ recorded highest TSS $(10.08$ ${ }^{\circ}$ Brix), this could be due to hydrolysis of starch and sucrose, might have led to increase in TSS content of flower stalk during early stages of vase life. Whereas, the decrease in TSS content in flower stalk towards the end of vase life might be due to their maximum utilization because of increased respiration rate.

\subsection{Anthocyanin content of ligules}

From the recorded data in (Figure 2). we noticed that neem extract at $1 \%$ supplemented with $4 \%$ sucrose recorded lowest

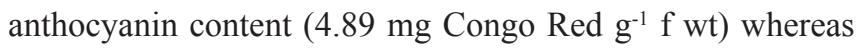
control (distilled water) recorded highest anthocyanin content (5.83 $\mathrm{mg}$ Congo Red $\mathrm{g}^{-1} \mathrm{f} \mathrm{wt}$ ) followed by lime juice at $2 \%+4 \%$ sucrose (5.65 mg Congo Red $\mathrm{g}^{-1} \mathrm{f} \mathrm{wt}$ ) without any significant difference. Anthocyanin content of cut gerbera flowers was decreased initially which might be due to dilution of anthocyanin in the expanding cells, while increase in anthocyanin content in later stage might be due to accumulation of oxidative products of polyphenols which enhanced the intensity of petal colour (Dhekney et al., 2000).

\subsection{Optical density}

Data in (Table 2). indicated that the lowest optical density was recorded with neem extract at $1 \%(0.041)$ as compared with all other treatments whereas control (distilled water) registered highest optical density value (0.088). Lowest optical density in neem extract at $1 \%+4 \%$ sucrose might be due to its antimicrobial activity that acts as a biocide in vase solution and resulted in reduced microbial growth which led to lowest turbidity of vase solution.

\subsection{Vase life}

Data presented in (Table 2). revealed that the highest vase life was recorded in treatment neem extract at $1 \%$ supplemented with $4 \%$ sucrose (11.76 days) followed by sugar at $4 \%$ (10.08 days) whereas control (distilled water) registered significantly lowest vase life period (4.53 days). Sucrose helps in maintaining water balance and turgidity. Hence, addition of sucrose and also antimicrobial nature of neem extract might have increased water relations which inturn enhanced the vase life of cut gerberas.

\subsection{Microbial population in vase solution}

At the end of vase life, lowest microbial population was recorded with treatment neem extract at $1 \%+$ sucrose at $4 \%\left(4.26 \times 10^{5} \mathrm{cfu} \mathrm{ml}^{-1}\right)$ because of antimicrobial nature of components present in neem extract and inhibited microbial growth as compared to other treatments. Whereas control (distilled water) registered highest microbial count $\left(9.11 \times 10^{6}\right.$ cfu $\mathrm{ml}^{-1}$ ) as presented in (Table 2).

Table 1: Effect of postharvest application of locally available preservatives on water relations and scape bending curvature during vase life period of cut gerbera cv. Savannah under ambient condition

\begin{tabular}{lcccc}
\hline Treatments & \multicolumn{3}{c}{ Water relations } & $\begin{array}{c}\text { Scape bending } \\
\text { curvature (degree) }\end{array}$ \\
\cline { 2 - 4 } & Water uptake (g/f) & $\begin{array}{c}\text { Transpirational loss } \\
\text { of water }(\mathrm{g} / \mathrm{f})\end{array}$ & $\begin{array}{c}\text { Fresh weight change } \\
(\%)\end{array}$ & $11.49^{\mathrm{d}}$ \\
\hline $\mathrm{T}_{1}$ : Sugar 2\% & $7.89^{\mathrm{d}}$ & $8.44^{\mathrm{b}}$ & $81.56^{\mathrm{d}}$ & $6.04^{\mathrm{b}}$ \\
$\mathrm{T}_{2}$ : Sugar 4\% & $8.84^{\mathrm{b}}$ & $9.16^{\mathrm{a}}$ & $90.59^{\mathrm{b}}$ & $8.37^{\mathrm{c}}$ \\
$\mathrm{T}_{3}$ : Commercial vinegar 2\% & $8.37^{\mathrm{c}}$ & $8.40^{\mathrm{b}}$ & $83.92^{\mathrm{c}}$ & $11.67^{\mathrm{d}}$ \\
$\mathrm{T}_{4}$ : Commercial vinegar 4\% & $7.77^{\mathrm{d}}$ & $7.68^{\mathrm{c}}$ & $80.77^{\mathrm{d}}$ & $12.09^{\mathrm{d}}$ \\
$\mathrm{T}_{5}$ : Lime juice 2\% & $7.95^{\mathrm{d}}$ & $7.52^{\mathrm{d}}$ & $79.46^{\mathrm{d}}$ & $11.90^{\mathrm{d}}$ \\
$\mathrm{T}_{6}$ : Lime juice 4\% & $7.71^{\mathrm{d}}$ & $7.61^{\mathrm{c}}$ & $80.27^{\mathrm{d}}$ & $7.80^{\mathrm{c}}$ \\
$\mathrm{T}_{7}$ : Commercial bleach 50 ppm & $8.55^{\mathrm{b}}$ & $8.57^{\mathrm{b}}$ & $85.54^{\mathrm{c}}$ & $11.58^{\mathrm{d}}$ \\
$\mathrm{T}_{8}:$ Commercial bleach 100 ppm & $7.82^{\mathrm{d}}$ & $7.75^{\mathrm{c}}$ & $81.03^{\mathrm{d}}$ & $4.16^{\mathrm{a}}$ \\
$\mathrm{T}_{9}$ : Neem extract 1\% & $9.36^{\mathrm{a}}$ & $9.31^{\mathrm{a}}$ & $94.84^{\mathrm{a}}$ & $8.07^{\mathrm{c}}$ \\
$\mathrm{T}_{10}:$ Neem extract 2\% & $8.42^{\mathrm{c}}$ & $7.90^{\mathrm{c}}$ & $84.99^{\mathrm{c}}$ & $29.47^{\mathrm{e}}$ \\
$\mathrm{T}_{11}$ : Control (Distilled water) & $5.65^{\mathrm{e}}$ & $6.68^{\mathrm{e}}$ & $78.40^{\mathrm{e}}$ & 0.45 \\
$\mathrm{SEm} \pm$ & 0.13 & 0.11 & 0.86 & 1.26 \\
$\mathrm{CD}(p=0.01)$ & 0.38 & 0.32 & 2.42 & \\
\hline
\end{tabular}

Values are the mean of three replications; Values with same alphabets did not differ significantly 


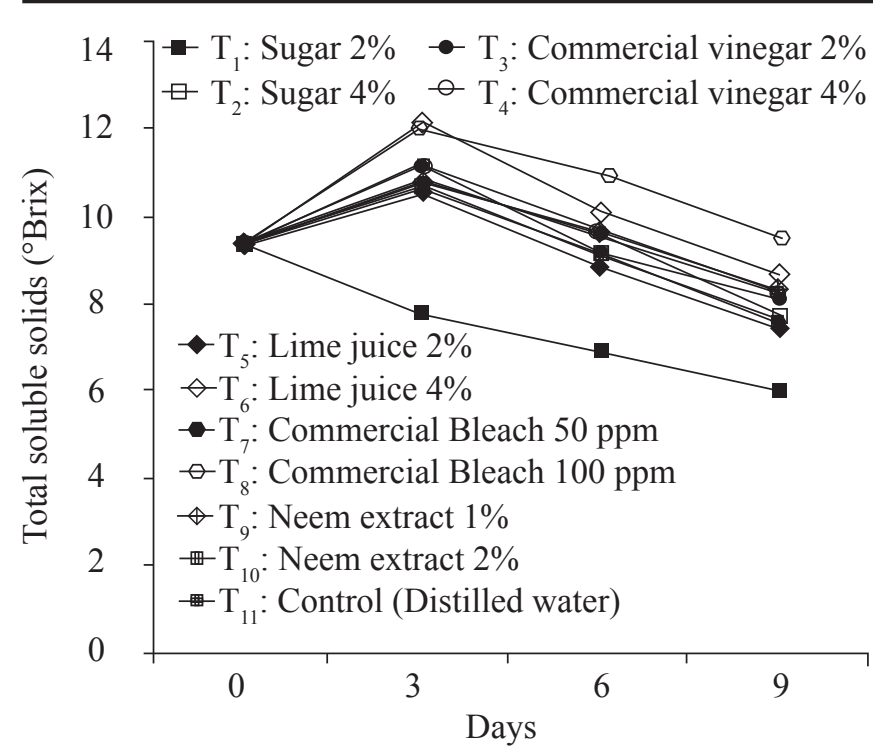

Figure 1: Effect of postharvest application of locally available preservatives on total soluble solids ( ${ }^{\circ}$ Brix) of cut gerbera $\mathrm{cv}$. Savannah under ambient storage

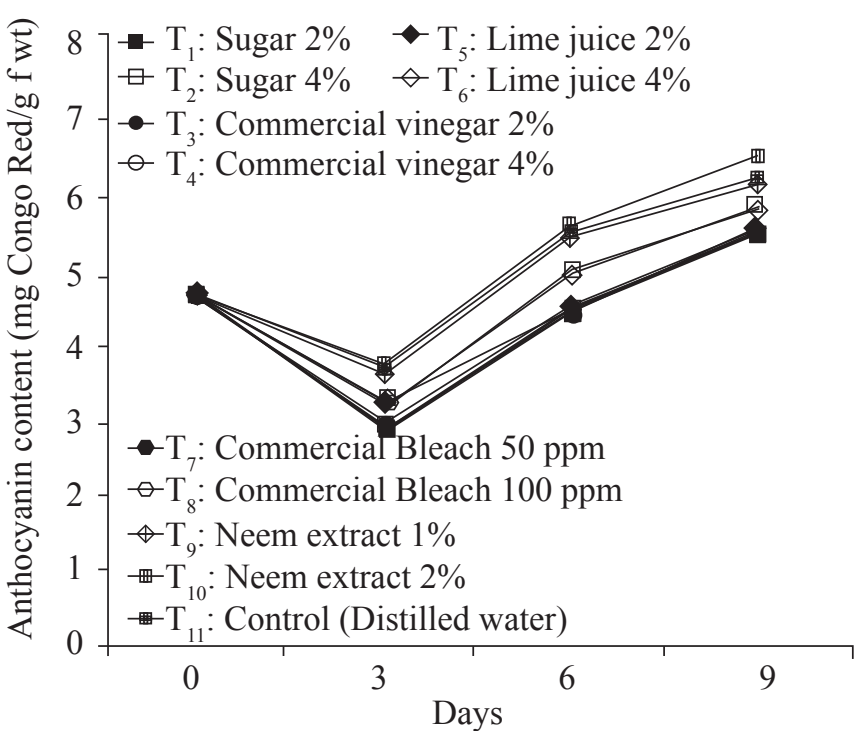

Figure 2: Effect of postharvest application of locally available preservatives on anthocyanin content ( $\mathrm{mg}$ Congo Red $\left.\mathrm{g} \mathrm{f} \mathrm{wt} \mathrm{t}^{-1}\right)$ of cut gerbera cv. Savannah under ambient storage

Table 2: Effect of postharvest application of locally available preservatives on optical density, microbial count in vase solution $\left(\mathrm{cfu} \mathrm{ml}^{-1}\right)$ and vase life period of cut gerbera cv. Savannah under ambient condition

\begin{tabular}{|c|c|c|c|c|}
\hline \multirow[t]{2}{*}{ Treatments } & \multirow[t]{2}{*}{ Optical density } & \multirow[t]{2}{*}{ Vase life (days) } & \multicolumn{2}{|c|}{ Microbial count } \\
\hline & & & $0^{\text {th }}$ day & $12^{\text {th }}$ day \\
\hline $\mathrm{T}_{1}:$ Sugar $2 \%$ & $0.054^{\mathrm{c}}$ & $7.93^{\mathrm{d}}$ & $3.21 \times 103^{b}$ & $6.53 \times 106^{c}$ \\
\hline $\mathrm{T}_{2}:$ Sugar $4 \%$ & $0.047^{\mathrm{b}}$ & $10.08^{\mathrm{b}}$ & $2.42 \times 103^{\mathrm{a}}$ & $4.88 \times 105^{\mathrm{a}}$ \\
\hline $\mathrm{T}_{3}:$ Commercial vinegar $2 \%$ & $0.054^{\mathrm{c}}$ & $8.46^{\mathrm{c}}$ & $3.01 \times 103^{\mathrm{b}}$ & $5.57 \times 106^{\mathrm{b}}$ \\
\hline $\mathrm{T}_{4}:$ Commercial vinegar $4 \%$ & $0.062^{\mathrm{d}}$ & $7.74^{\mathrm{d}}$ & $3.52 \times 103^{c}$ & $6.71 \times 106^{c}$ \\
\hline $\mathrm{T}_{5}:$ Lime juice $2 \%$ & $0.064^{\mathrm{d}}$ & $7.44^{\mathrm{d}}$ & $3.71 \times 103^{\mathrm{c}}$ & $7.11 \times 106^{\mathrm{c}}$ \\
\hline $\mathrm{T}_{6}:$ Lime juice $4 \%$ & $0.064^{\mathrm{d}}$ & $7.60^{\mathrm{d}}$ & $3.64 \times 103^{c}$ & $6.92 \times 106^{c}$ \\
\hline $\mathrm{T}_{7}$ : Commercial bleach $50 \mathrm{ppm}$ & $0.053^{\mathrm{c}}$ & $8.94^{\mathrm{c}}$ & $2.83 \times 103^{b}$ & $5.01 \times 106^{\mathrm{b}}$ \\
\hline $\mathrm{T}_{8}$ : Commercial bleach $100 \mathrm{ppm}$ & $0.062^{\mathrm{d}}$ & $7.82^{\mathrm{d}}$ & $3.41 \times 103^{b}$ & $6.64 \times 106^{\mathrm{b}}$ \\
\hline $\mathrm{T}_{9}:$ Neem extract $1 \%$ & $0.041^{\mathrm{a}}$ & $11.76^{\mathrm{a}}$ & $1.96 \times 103^{\mathrm{a}}$ & $4.26 \times 105^{\mathrm{a}}$ \\
\hline $\mathrm{T}_{10}:$ Neem extract $2 \%$ & $0.061^{\mathrm{d}}$ & $8.53^{\mathrm{c}}$ & $2.96 \times 103^{b}$ & $5.23 \times 106^{b}$ \\
\hline $\mathrm{T}_{11}:$ Control (Distilled water) & $0.088^{\mathrm{e}}$ & $4.53^{\mathrm{e}}$ & $4.45 \times 103^{\mathrm{d}}$ & $8.99 \times 106^{\mathrm{d}}$ \\
\hline $\mathrm{SEm} \pm$ & 0.001 & 0.21 & 0.23 & 0.22 \\
\hline $\mathrm{CD}(p=0.01)$ & 0.004 & 0.62 & 0.68 & 0.67 \\
\hline
\end{tabular}

Values are the mean of three replications, Values with same alphabets did not differ significantly

\section{Conclusion}

Neem (Azadirachta indica) extract at $1 \%$ supplemented with $4 \%$ sucrose is most effective locally available preservative which can be successfully used to extend the vase life of cut gerberas as it is biocidal in nature that prevented microbial growth which causes vascular blockage.

\section{Acknowledgement}

Authors wish to thank $\mathrm{COH}$, Mojerla, Dr. YSRHU for providing the laboratory facilities. The assistance of students is also duly acknowledged.

\section{References}

Abadi, M.A.R.H., Moghadam, A.R.L., Abdossi, V., 2013. The affected postharvest life of gerbera cut flowers by the application of silver nitrate, silver thiosulfate and nano silver. International Research Journal of Applied and Basic Sciences 4(4), 806-809.

Balestra, G.M., Agostini, R., Bellincontro, A., Mencarelli, F., Varvaro, L., 2005. Bacterial populations related to gerbera (Gerbera jamesonii L.) stem break. Phytopathologia Mediterranean 44, 291-299.

Bleeksma, H.C., Van Doorn, W.G., 2003. Embolism in rose 
stems as a result of vascular occlusion by bacteria. Postharvest Biology and Technology 334-340.

Chandrasekhar, S.Y., Gopinath, G., 2000. Influence of chemicals and organic extracts on the postharvest behaviour of carnation cut flowers. Karnataka Journal of Agricultural Sciences 17(1), 81-85.

Dhekney, S.A., Ashok, A.D., Rengasamy, P., 2000. Action of various growth regulators and floral preservatives on vase life of cut rose cv. First Red growth under controlled conditions. South Indian Horticulture 48(1-6), 69-71.

Soad, M.M.I., Lobna, S.T., Rawia, A.Eid., 2011. Extending postharvest life and keeping quality of gerbera cut flowers using some chemical preservatives. Journal of Applied Sciences Research 7(7), 1233-1239.

Mor, Y.H., Hardenburg, R.E., Kofranek, A.M., Reid, M.S., 1981. Effect of silver-thiosulfate pretreatment on vase life of cut standard carnations, spray carnations and gladiolus after transcontinental truck shipment. Hort Science 16, 766-768.

Mousa, S., Mosen, K., Toktam, S.T., Roohangiz, N., 2009. Essential oils and silver nanoparticles (SNP) as novel agents to extend vase life of gerbera (Gerbera jamesonii cv. Dune) flowers. Postharvest Biology and Technology 53(3), 155-158.

Mutui, T.M., 2002. Postharvest handling of cut flowers. Proceedings of the Horticulture Seminar on Sustainable Horticultural Production in the Tropics, Jomo Kenyatta University of Agriculture and Technology, JKUAT, Kenya 3-5.

Panse, V.G., Sukhatme, P.V., 1989. Statistical methods for agriculture workers. Indian Council for Agricultural Research, New Delhi, 359.
Prashanth, P., Chandrasekhar, R., 2007. Effect of biocides in vase solution on scape bending and senescence in cut flower of gerbera (Gerbera jamesonii Bolus ex. Hook.). Journal of Ornamental Horticulture 10(3), 137-142.

Thwala, M., Paul, K.W., Tajudeen, O.O., Michael, T.M., 2013. Effect of floral preservatives on the vase life of orchid (Epidendrum radicans L.) cut flowers. Journal of Horticultural Science and Ornamental Plants 5(1), 22-29.

Tsegaw, T., Tilahun, S., Humphries, G., 2011. Influence of pulsing biocides and preservative solution treatment on the vase life of cut rose (Rosa hybrida L.) varieties. Ethiopian Journal of Applied Science and Technology 2(2), 1-15.

Rutland, R.B., 1968. The effect of temperature on the concentration of anthocyanin in pink flowers of chrysanthemum morifolium Ram cv. Orchid Queen. Proceedings of the American Society for Horticultural Sciences 93, 576-582.

Wernett, H.C., Sheehan, T.J., Wilfret, G.J., Marousky, P.M., Lyrene, P.M., Knauft, D.A., 1996. Postharvest longevity of cut flower gerbera in response to selection for vase life components. Journal of American Society for Horticultural Sciences 121, 216-221.

Van Doorn, W.G., De Wittee, Y., 1994. Effect of bacteria on scape bending in cut Gerberajamesonii flowers. Journal of American Society of Horticultural Sciences 119, 568-571.

Venkatarayappa, T., Murr, D.P., sujita, T.M., 1981. Effect of $\mathrm{Co}_{2}+$ and sucrose on the physiology of cut Samantha roses. Journal of Horticultural Science 56, 21-25. 